\title{
NEW SPECIES OF NORTH AMERICAN CYRTIDAE
}

By Charles W. Johnson.

Boston Society of Natural History.

Acrocera stansburyi sp. nov.

$0^{T}$ \% Head black, occiput with whitish tomentum, antennæ yellow. Thorax yellow with three broad narrowly separated black stripes (in two specimens, male and female, the stripes are fused, forming a large trilobed mark), the dorsal stripe is truncate behind at a line corresponding with the base of the wings, the lateral stripes are truncate in front at about the middle of the dorsal stripe, becoming gradually narrower behind and reaching the post-alar callosities, tomentum whitish, pleura on the upper half yellow, with large, irregular, black spots, which are connected with the black of the lower half, humeri and postalar callosities whitish, scutellum yellow, metanotum black. Abdomen yellow, the second segment is margined anteriorly with black expanding centrally and forming a dorsal triangle, a small dorsal triangle is also present at the base of the third and the fourth, with a small spot usually present on the side of the third, in one specimen there is a narrow margin similar to that on the second segment, ventral segments blackish margined with yellow. Legs white, coxæ yellow, tips of the tarsi and claws black. Wings hyaline, venation as in O. liturata Will., squamæ white, halteres yellow. Length, $3 \mathrm{~mm}$.

Eight specimens, Stansbury Island, Great Salt Lake, Utah, July 13, 1913 (Hagan and Titus). Holotype and three paratypes in the author's collection. Two paratypes in the collection of Mr. H. R. Hagan, one in the Museum of Comparative Zoology, and one in the U. S. National Museum.

I had referred this to A. liturata, but it is evidently quite different, as indicated by the thoracic and abdominal markings and the color of the scutellum. At the request of Mr. Hagon I am dedicating it to Howard Stansbury, who made and elaborate survey of Great Salt Lake and vicinity in 1849 and 1850. 
Ocnaea auripilosa sp. nov.

o Head black, eyes hairy, antennæ brown, second joint about one half the length of the first (third joint wanting). Thorax, including the pleura and scutellum honey-yellow, shining and covered with quite thick yellow pile, humeri prominent and lighter than the disc of the thorax, behind the shoulder is a whitish stigma, narrowly margined with black, sternum black. Abdomen bright orange-yellow, with short golden pile; the segments have the following blue-black markings, - a spot in the middle of the first, a triangle at the base of the second and third, a square occupying the middle half of the fifth and all of the sixth segment except a narrow margin, venter yellow. Legs yellow with yellow pile, tips of the tarsi dark brown,claws black. Wings hyaline, veins yellow, squamæ white margined with black and fringed with yellow hairs; the first posterior cell is closed and petiolate. Length $11 \mathrm{~mm}$., the abdomen is about double the width of the thorax.

One specimen, Tucson, Arizona, March 16, 1916 (J. F. Tucker). Type in the author's collection. It agrees somewhat with O. micans Erichson, but its yellow not "fuscous" color, the blueblack abdominal markings and larger size separate it from that species.

\section{Ogocodes vittatus sp. nov.}

i Head black, antennæ dark brown. Thorax reddish brown, with three broad black stripes, the lateral stripes abbreviated anteriorly and the dorsal stripe obsolete posteriorly, humeri,post-alar callosities, metanotum, and upper parts of the pleura yellow, a blackish spot in front of the base of the wing, and the lower part of the pleura shining black, scutellum black, the base brownish on the sides. Abdomen black, shining, with the posterior margins of the segments narrowly edged with yellow, venter yellow. Legs brownish, the knees yellow, the posterior tibiæ and tarsi black. Wings and squamæ light brown, veins dark brown, knobs of the halteres blackish, stems yellow. Length $4.5 \mathrm{~mm}$. 
One specimen, Middlesex County, New Jersey, May 19, (Harry B. Weiss). Type in the author's collection. This is readily separated from all the described species by its striped thorax.

The Zoological Record.

The attention of Entomologist thoughout the world is called to the fact that, beginning with the Volume for 1922, the preparation of the "Insecta" part of the "Zoological Record," is being undertaken by the Imperial Bureau of Entomology. In order that the Record may be as complete as it is possible to make it, all authors of entomological papers, especially of systematic ones, are requested to send separata of their papers to the Bureau. These are particularly desired in cases where the original journal is one that is not primarily devoted to entomology All separata should be addressed to:-

The Assistant Director,

Imperial Bureau of Entomology,

41, Queen's Gate,

London, S. W. 7,

England. 

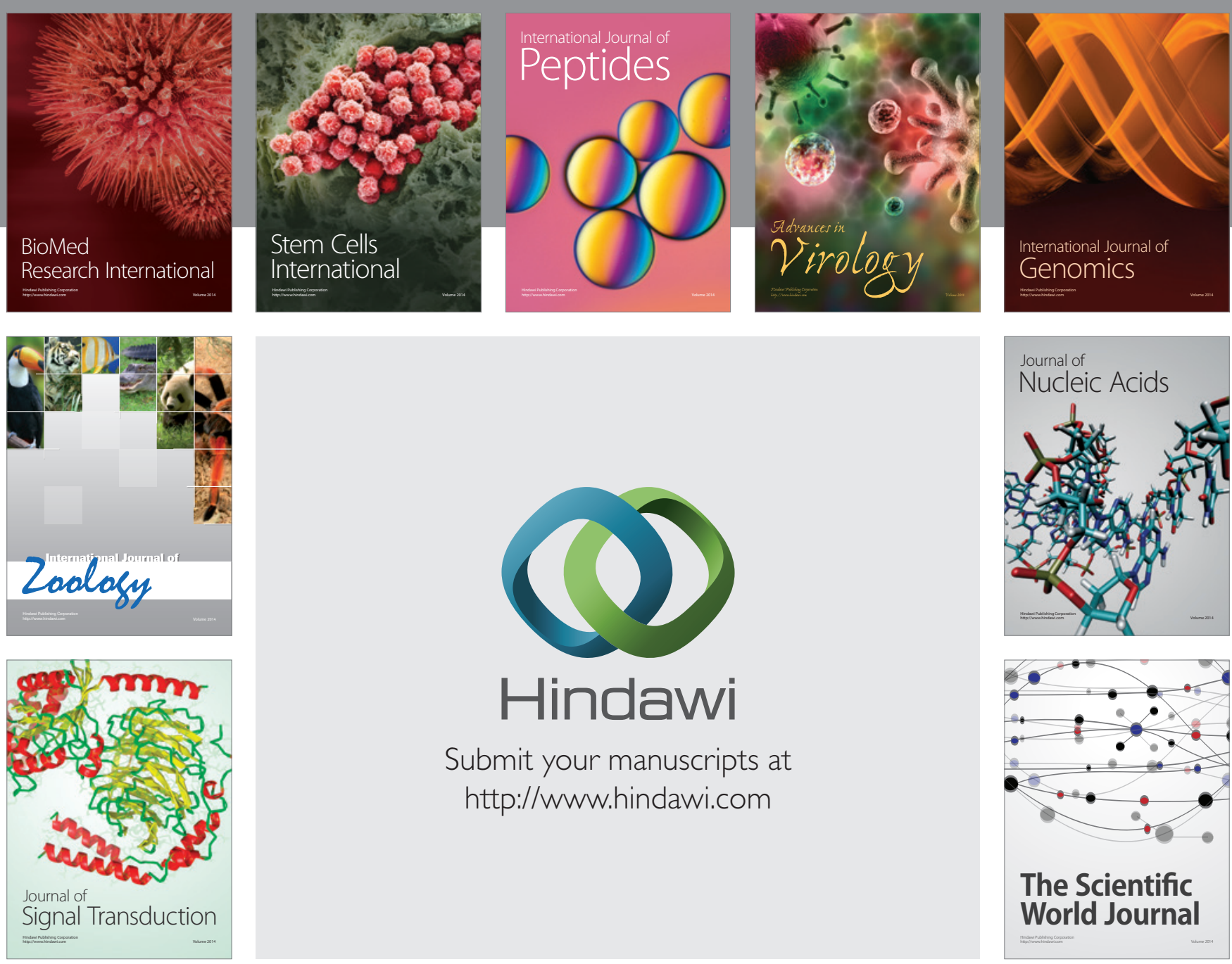

Submit your manuscripts at

http://www.hindawi.com
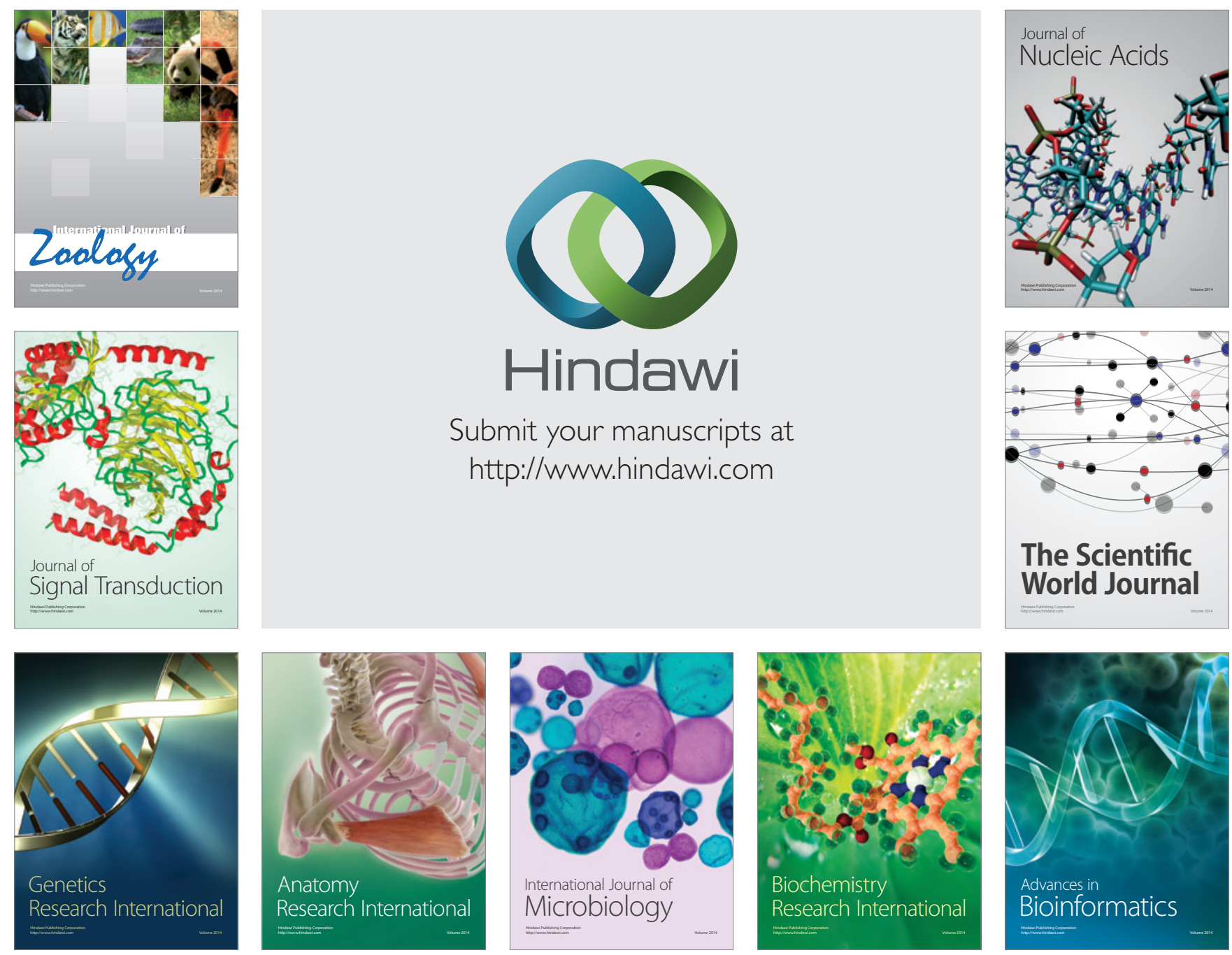

The Scientific World Journal
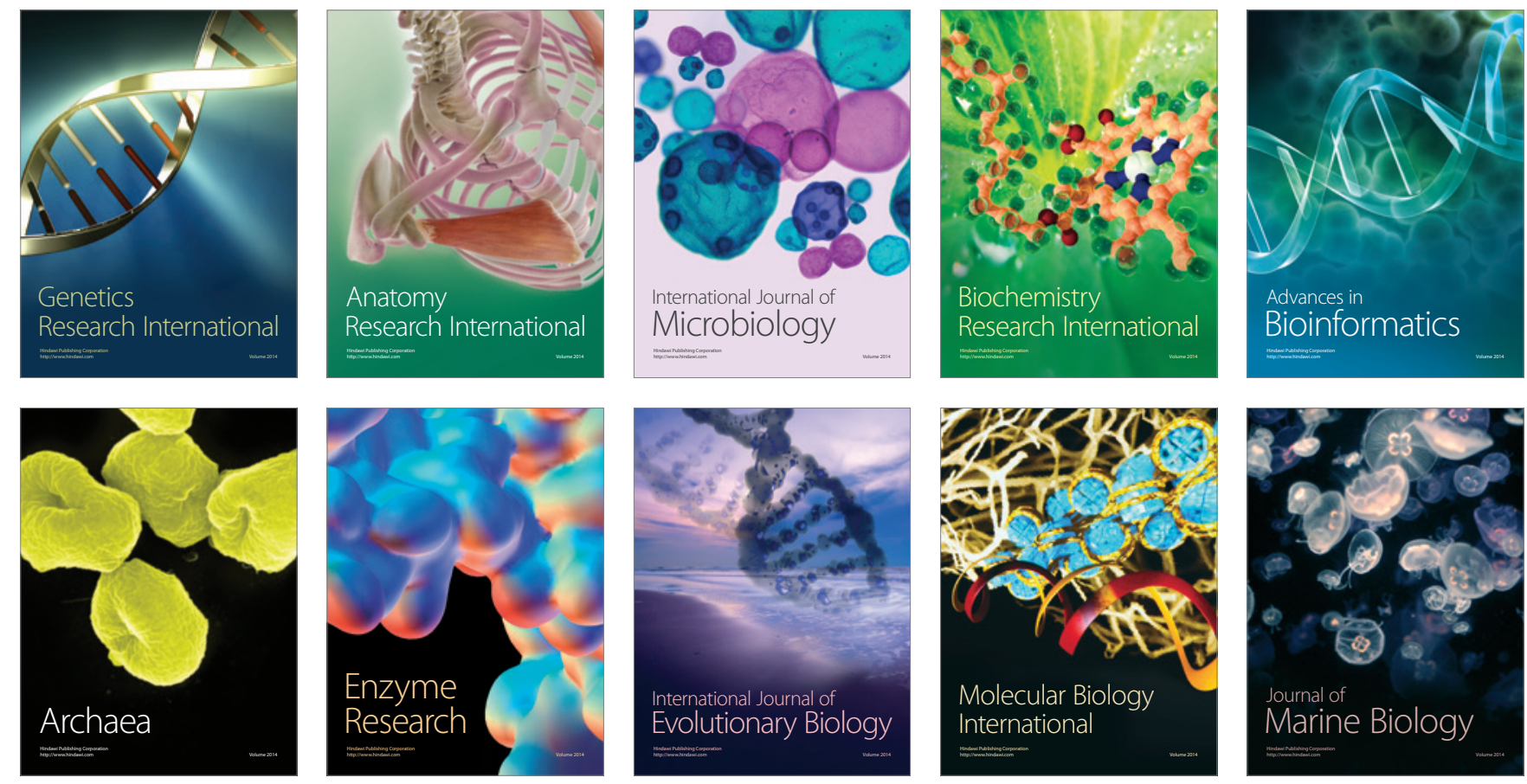